\title{
RESPONSIVE AND PROACTIVE MARKET ORIENTATION AND INNOVATION SUCCESS UNDER MARKET AND TECHNOLOGICAL TURBULENCE
}

\author{
Mateja Bodlaj ${ }^{1}$, Germa Coenders², Vesna Zabkar ${ }^{3}$ \\ ${ }^{1,3}$ Faculty of Economics, Department of Marketing, Kardeljeva ploscad 17, \\ University of Ljubljana, SI-1000 Ljubljana, Slovenia \\ ${ }^{2}$ Faculty of Economics and Management, Department of Economics, \\ Montilivi Campus, University of Girona, E-17071 Girona, Spain \\ E-mails: ${ }^{1}$ mateja.bodlaj@ef.uni-lj.si (corresponding author); \\ ${ }^{2}$ germa.coenders@udg.edu; ${ }^{3}$ vesna.zabkar@ef.uni-lj.si
}

Received 27 January 2011; accepted 11 February 2012

\begin{abstract}
The study investigates how market and technological changes in an organization's business environment moderate the relationships between responsive and proactive market orientation, innovation success, and market success of the organization. The respondents in the study were senior managers of companies operating in a Central European country. The Internet survey resulted in 441 usable questionnaires. Data were analyzed using a non-linear structural equation models with MPLUS5. The results provide support for distinguishing between the two complementary forms of market orientation, proactive and responsive. While proactive market orientation is a determinant of both innovation and market success of the organization, the impact of responsive market orientation on the innovation and market success is positive and significant only in a rapidly changing market environment. Companies can improve their innovation success and in turn market success by improving their proactive market orientation, i.e. by investing resources in exploring customer needs, customer problems with existing products and latent customer needs. The study contributes to the literature by examining the entire chain of relationships between market orientation, innovation success and market success by adopting both a responsive and proactive market orientation. It is the first study that examines these relationships in the context of companies from a European country and with consideration of market turbulence/changes.
\end{abstract}

Keywords: proactive and responsive market orientation, innovation success, market and technological changes.

Reference to this paper should be made as follows: Bodlaj, M.; Coenders, G.; Zabkar, V. 2012. Responsive and proactive market orientation and innovation success under market and technological turbulence, Journal of Business Economics and Management 13(4): 666-687.

JEL Classification: M30, M31.

\section{Introduction}

Recent market orientation literature has stressed the importance of distinguishing between two complementary forms of market orientation: responsive and proactive. Grin- 
stein (2008) calls for more studies that would distinguish between these constructs, their antecedents, and consequences. For Atuahene-Gima et al. (2005) and Tsai et al. (2008), responsive and proactive market orientations are important determinants of new product performance. Through developing a market orientation, organizations can build up an edge over competitors in innovation and enhance innovation consequences in the competitive environments in which they operate (Grinstein 2008). This said, the question then becomes "Do both responsive and proactive market orientations enhance innovation consequences?"

The key research issues of this study are the relationships between market orientation, innovation success, and market success, with a distinction made between the responsive or proactive form of market orientation. In examining these issues, this study aims to scan how adopting a proactive or responsive market orientation influences innovation success when both the market and technology are turbulent/changing. Extensive literature has already examined how market orientation influences the market success of the organization. However, the impact of market orientation on innovation has received much less research attention (see Han et al. 1998; Kirca et al. 2005). Knowledge about the relationship between market orientation and innovation remains fragmented and uncompleted (Lukas, Ferrell 2000). To date, few empirical studies (Narver et al. 2004; Atuahene-Gima et al. 2005; Tsai et al. 2008) have examined the impact of responsive and proactive market orientation on new product success. None of these studies has examined the entire chain of relationships between market orientation, innovation and market success and the moderating effect of market changes in the market orientationinnovation success relationship. While Tsai et al. (2008) examined the contingent effects of the technological change on the relationship between responsive and proactive market orientations and new product success; they only obtained results from a high-tech sector. The reality is that the majority of organizations are not necessarily in the high-tech sector. To fill this research gap, our study addresses the relationship between market orientation, innovation success, and market success under the moderating effect of market and technological turbulence in a cross-sector sample. Included are organizations from diverse, high-tech and non-high-tech sectors and industries. The study is based on subjective data, i.e. managers' perceptions of constructs under review.

\section{Theoretical background}

\subsection{Market orientation and innovation success}

According to Narver et al. (2004), a responsive market orientation refers to discovering, understanding, and satisfying expressed customer needs. In contrast, a proactive market orientation refers to discovering, understanding, and satisfying latent customer needs. Although the two most frequently mentioned definitions of market orientation from the early 1990s refer to the importance of understanding present and future target customers (Narver, Slater 1990) and gathering information about present and future customer needs (Kohli, Jaworski 1990), past measures of market orientation were focused predominantly on the responsive market orientation (Narver et al. 2004). Similarly, Jaworski et al. (2000) claimed that market orientation is often interpreted too narrowly 
as adopting the offer to the current customer preferences and/or market structure (i.e., market-driven) compared to proactively shaping customers and/or the market to enhance a company's competitive position (i.e., market driving). While responsive market orientation is generally regarded as being market-driven, proactive market orientation is more compatible with the concept of market driving (Mohr, Sarin 2009). Both forms are needed for the long-run business performance (Sheth, Sisodia 1999).

A responsive market orientation (also referred as "customer led") is short-term focused and can be successful in relatively predictable and stable environments. In dynamic environments, however, this form of market orientation rarely leads to competitive advantage, because it does not provide sufficient incentive for important innovations (Slater, Narver 1998). A responsive market-oriented company focuses largely on its current knowledge and experience to satisfy expressed customer needs, thereby reflecting exploitative (Atuahene-Gima et al. 2005; Tsai et al. 2008) or adaptive learning (Slater, Narver 1998). In contrast, a proactive market-oriented company explores new knowledge and markets significantly distant from extant experience (Tsai et al. 2008), thereby reflecting exploratory (Atuahene-Gima et al. 2005; Tsai et al. 2008) or generative learning (Slater, Narver 1998).

In general, market orientation is an important factor of successful new product development and innovation success, because new products should deliver value for customers (Jensen, Harmsen 2001). Innovation success refers to success of new products being launched on time, capturing market share and contributing to total company sales (Cooper, Kleinschmidt 1995; Griffin, Hauser 1996). Various empirical studies have confirmed a positive relationship between a market orientation and new product success (e.g., Cooper 1994; Cooper, Kleinschmidt 1994; Cahill et al. 1994; Jensen, Harmsen 2001; Pelham, Wilson 1996; Baker, Sinkula 1999a, 1999b, 2005; Gray et al. 1999; Wren et al. 2000; Lado, Maydeu-Olivares 2001; Matsuno et al. 2002; Papastathopoulou et al. 2006). The impact of market orientation, however, is greater when the new product represents an incremental change for both the customer and the company; when the perceived competitive intensity and hostility are high; and during the earlier stages of the product life cycle (Atuahene-Gima 1995). Langerak et al. (2004), on the other hand, found that market orientation is not directly related to new product success. Moreover, findings of three meta-analyses were not unequivocal. Henard and Szymanski (2001) reported a statistically insignificant corrected mean correlation, while Kirca et al. (2005) and Grinstein (2008) reported a positive correlation between market orientation and innovation consequences (i.e., new product success and innovativeness). However, in the above mentioned empirical studies, market orientation has been viewed primarily as responsive.

Among few empirical studies that have examined the relationship between market orientation and innovation success by adopting both a responsive and proactive market orientation, Narver et al. (2004) reported only a proactive market orientation being positively and significantly related to new product success, while Atuahene-Gima et al. (2005) and Tsai et al. (2008) found the need for both forms of market orientation. The latter two studies revealed a more complex nature of the relationship. For example, 
Atuahene-Gima et al. (2005) reported that new product success is enhanced when one market orientation form is at a higher level and the other is at a lower level. Tsai et al. (2008) suggested that the curvilinear relationship between the two market orientations and new product success might depend on the external environment.

It seems that relying solely on customers' expressed needs creates no new insights into opportunities to add customer value; hence, it may be insufficient for responsive market oriented organization to attract and retain customers (Narver et al. 2004). Considering only expressed customer needs leads to a "tyranny of the served market" (Hamel, Prahalad 1991) and can explain why such companies are only "followers" (Hamel, Prahalad 1991; Berthon et al. 2004) with a considerably lower capacity to innovate (Christensen, Bower 1996). On the other hand, with a proactive market orientation, latent, unarticulated needs can often be discovered by carefully observing customer behaviors to discover problems customers have and to uncover new market opportunities. This is done by, for example, working closely with lead users or undertaking experiments to discover future needs (Slater, Narver 1998; Slater 2001; Atuahene-Gima et al. 2005). In line with the above, we predict the following:

H1a: The higher the level of proactive market orientation, the stronger the innovation success.

H1b: The higher the level of responsive market orientation, the stronger the innovation success.

The impact of proactive market orientation on innovation success is expected to be stronger than the impact of responsive market orientation.

\subsection{Market orientation and market success}

A significant body of empirical research (e.g., Narver, Slater 1990; Slater, Narver 1994; Jaworski, Kohli 1993; Baker, Sinkula 1999a; Hooley et al. 2000; Gonzalez-Benito et al. 2009) along with three meta-analyses (Cano et al. 2004; Kirca et al. 2005; Ellis 2006) confirm a positive relationship between market orientation and business performance. More specifically, Kirca et al. (2005), based on their meta-analysis, reported a positive correlation with both measures of market success (e.g., sales, market share, customer satisfaction, customer loyalty, perceived quality) and measures of financial success (e.g., profit). Further, empirical findings have confirmed that market performance is positively related to financial performance (e.g., Homburg, Pflesser 2000; Anderson et al. 2004; Hooley et al. 2005; Gruca, Rego 2005). To date, only one empirical study has examined the relationship between market orientation and business success by exploring both responsive and proactive approaches. Voola and O'Cass (2010) found that both orientations are positively related to business success, yet the impact of proactive market orientation is stronger.

On the other hand, innovation has been increasingly emphasised as one of the most important drivers of business performance (e.g., Deshpande et al. 1993; Hult, Ketchen 2001; Deshpande, Farley 2004; Fagerberg 2005; Davila et al. 2006; Mohr, Sarin 2009). 
The effect of market orientation on market success may largely operate indirectly via the relationship between market orientation and innovation success proposed in H1a and $\mathrm{H} 1 \mathrm{~b}$ as well as the relationship between innovation and market success, which is repeatedly found in the literature. In line with extant empirical findings on the market orientation-business success relationship, we expect that:

H2a: The higher the level of proactive market orientation, the stronger the market success via stronger innovation success.

H2b: The higher the level of responsive market orientation, the stronger the market success via stronger innovation success.

\subsection{Moderating effect of market and technological changes}

Assuming that market orientation may be more important in certain environments (e.g., Day, Wensley 1988; Kohli, Jaworski 1990), a number of researchers have empirically examined the role of the business environment in the relationship between market orientation and business performance (e.g., Jaworski, Kohli 1993; Diamantopoulos, Hart 1993; Slater, Narver 1994). A market orientation literature review reveals that market and technological change/turbulence are among the most frequently examined environmental turbulence moderators (Kirca et al. 2005). Market turbulence refers to changes in the composition of customers and their preferences (Kohli, Jaworski 1990; Jaworski, Kohli 1993), whereas technological turbulence is the considered rate of technological change (Jaworski, Kohli 1993; Tsai et al. 2008). Other related conceptualizations, however, could be found as well. For example, Homburg and Pflesser (2000) examined the role of market dynamism, measured by changes in competitors' product offers, sales strategies, and marketing communications strategies. For Hooley et al. (2003), market turbulence includes (1) stage of product life cycle, (2) the speed at which customer requirements change, (3) the speed at which the technology employed changes, and (4) the degree of competition. Calantone et al. (2003) define turbulent environment as one in which frequent and unpredictable market and/or technological changes within an industry accentuate risk and uncertainty in the new product development strategic planning process. To summarize, there is no single approach in defining and measuring environmental turbulence. While some authors explicitely distinguish between demandside (e.g. customer preferences) and supply-side characteristics (e.g., technology), others apply a broader definition which includes variables from both groups. The first approach is more common in the market orientation literature. Perceived changes in customer needs/wants and in buying behavior as well as the rate of technological change are of interest in this study.

When customer preference sets are less stable, a greater likelihood exists that the company's offerings will become mismatched with customers' needs over a period of time (Kohli, Jaworski 1990), unless the company modifies its offerings to satisfy the customers' changing preferences. It is expected, therefore, that market orientation has a stronger effect on performance in the environment with higher levels of market turbulence (Kohli, Jaworski 1990; Jaworski, Kohli 1993). In contrast, market orientation 
may be less important in a more turbulent technological environment because companies may be able to obtain competitive advantage through technological innovation (Kohli, Jaworski 1990; Jaworski, Kohli 1993). Empirical findings on moderating effect of market and technological changes in the relationship between market orientation and business performance are discordant. Kumar et al. (1998) found that the positive effect of market orientation on business performance is stronger under higher levels of market turbulence, while others report the opposite (e.g. Slater, Narver 1994; Appiah-Adu 1998) or no moderating effect of market turbulence (e.g. Jaworski, Kohli 1993; Gray et al. 1999; Subramanian, Gopalakrishna 2001; Rose, Shoham 2002). Similarly, some authors report that the market orientation-business performance is stronger under lower levels of technological turbulence (e.g. Slater, Narver 1994; Greenley 1995), others report the opposite (e.g. Rose, Shoham 2002) or no moderating effect (e.g. Jaworski, Kohli 1993; Gray et al. 1999). To summarize, insufficient empirical evidence exists about market and technological changes as moderators of the market orientation-performance relationship (Kirca et al. 2005). It should be noted that past empirical studies have focused on various measures of business performance and only a few have focused on measures of innovation success. For example, there is some empirical support that market orientation may be more important for new product success at a lower level of technological change (Slater, Narver 1994; Greenley 1995). Similarly, Grinstein (2008), in his meta-analysis, reported that the relationship between market orientation and innovation consequences (i.e., new product success and innovativeness) is weaker in technologically turbulent environments. None of the above-mentioned studies, however, examines a responsive and proactive market orientation. As an exception, Tsai et al. (2008) hypothesize that under a high level of technological turbulence, a responsive market orientation becomes detrimental to new product success beyond a certain level. On the other hand, in a stable technological environment, a proactive market orientation becomes detrimental to new product success beyond a certain level. Tsai et al. (2008) did not study market turbulence, however. Hypotheses regarding a moderating effect of market changes on the relationship between both forms of market orientation and innovation success were therefore derived from the theoretical framework, proposed by Kohli and Jaworski (1990) and Jaworski and Kohli (1993): (see Fig. 1 for the conceptual model with key constructs and hypothesized paths):

H3a: The higher the level of perceived market changes, the stronger the positive effect of proactive market orientation on innovation success.

H3b: The higher the level of perceived market changes, the stronger the positive effect of responsive market orientation on innovation success.

H4a: The higher the level of perceived technological changes, the stronger the positive effect of proactive market orientation on innovation success.

H4b: The higher the level of perceived technological changes, the weaker the positive effect of responsive market orientation on innovation success. 


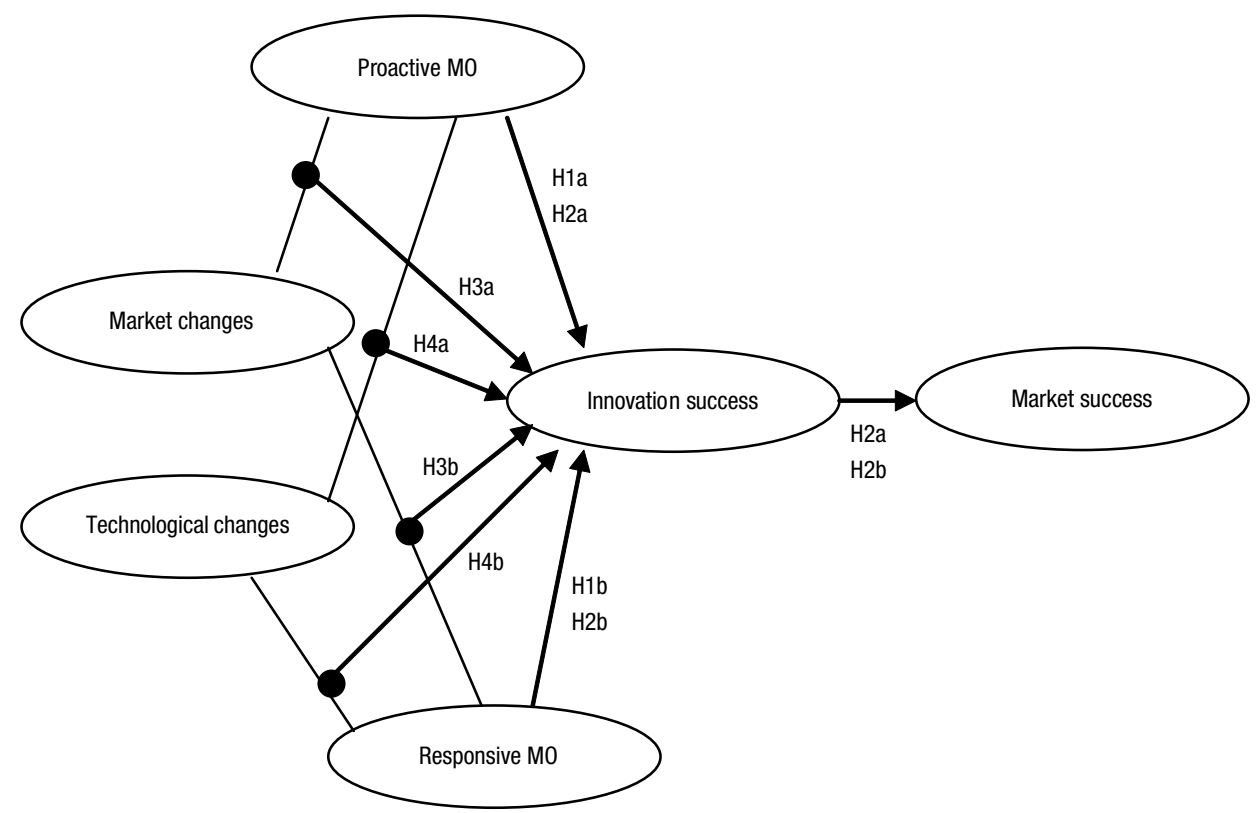

Fig. 1. A path diagram

\section{Method}

\subsection{Sample and data collection}

The study sample consisted of companies operating in a Central European country in manufacturing and selected services (wholesale and retail trade, transportation, storage and communications, and financial intermediation). Since cooperation between business functions was part of the survey, micro companies (less than 10 employees) were excluded (see also Hooley et al. 2003, 2005). A list of 3732 e-mail addresses of general managers and marketing managers was used as a sampling frame, compiled by a call centre at the country's Chamber of Commerce and Industry from the records of Agency for Public Legal Records and Related Services. Each manager was e-mailed a letter explaining the general purpose of the study and provided with a link to the Internet survey. Two follow-up emails were sent to non-respondents. The survey was conducted from January to March 2008. After accounting for undeliverable mails, usable questionnaires from 441 companies were received, constituting a $16 \%$ response rate. The sample consisted of $53 \%$ manufacturing and $47 \%$ service organizations. According to size, $53 \%$ were classified as small (10-49 employees); 32\% medium (50-249 employees) and $15 \%$ large companies (more than 250 employees). Among all respondents, 51\% were general managers, $31 \%$ were marketing managers, and the rest mainly held other leading positions in the company. Early and late respondents were compared as a test of nonresponse bias, and no significant differences were found. 


\subsection{Research instrument}

The questionnaire contained 20 items designed to measure the responsive and proactive market oriented behavior on a 7 -point Likert scale $(1=$ strongly disagree to $7=$ strongly agree). The items were developed based on a literature review of the existing measures of market orientation (e.g., Narver et al. 2004; Atuahene-Gima et al. 2005; Tsai et al. 2008; Kohli et al. 1993; Narver, Slater 1990) and findings from eight in-depth interviews with managers. The questionnaire was pre-tested with nine academics and 12 managers. In addition, the face validity of the market orientation scale was tested with two academics and four managers. Carefully examining the item content, the correlation matrices, and the results of exploratory and confirmatory factor analysis led to selecting the four most valid indicators for proactive orientation $\left(x_{1}\right.$ to $\left.x_{4}\right)$ and for responsive market orientation $\left(x_{5}\right.$ to $\left.x_{8}\right)$. See Table 1 .

Market and technological change were measured based on scales developed by Jaworski and Kohli (1993). The questionnaire contained four items designed to measure each of the two environmental changes (see Table 1). The respondents were asked to indicate their degree of agreement on a seven-point Likert scale $(1=$ strongly disagree to $7=$ strongly agree). Again using the procedure above, we selected the set of most valid indicators for market change $\left(x_{9}\right.$ to $\left.x_{11}\right)$ and technological change $\left(x_{12}\right.$ to $\left.x_{14}\right)$.

The success of the innovations that the company introduced during the past three years (2005-2007) was measured relative to the company's objectives $\left(y_{1}\right.$ to $y_{3}$ in a $1=$ very unsuccessful to 7 = very successful scale; see Table 1$)$. The measures were derived from the literature (e.g., Cooper 1994; Cooper, Kleinschmidt 1995; Griffin, Hauser 1996) and findings from in-depth interviews with managers. Finally, market success in 2007 was measured relative to major competitors $\left(y_{4}\right.$ to $y_{6}$ in a $1=$ much worse to $7=$ much better than major competitors scale; see Table 1). Past empirical studies have indicated a strong correlation between objective performance and subjective perceptions of managers (Dawes 1999).

\subsection{Research approach}

Moderated regression analysis (MRA) is a particular specification of multiple linear regression analysis that includes products of regressors. It has been widely used in the social sciences to model so-called interaction effects or moderator effects; in other words, when the value of a variable influences the effect of another variable on the dependent one (e.g., Irwin, McClelland 2001). Measurement error, however, causes the estimates of regression coefficients in MRA to be biased.

To account for measurement error bias, Kenny and Judd (1984) proposed a possible specification for modeling interaction effects with structural equation models (SEM). Kenny and Judd's (1984) approach implied forming multiple indicators based on the products of the observed variables and of complex non-linear parameter constraints. These products are then used as indicators of the latent interaction. Jaccard and Wan (1996), Jöreskog and Yang (1996), Marsh et al. (2004) and Coenders et al. (2008) refined Kenny and Yudd's (1984) approach to make it more robust and easier to use in applied research. In this study, we use the Coenders et al. (2008) variant, which was found by the authors and by Lin et al. (2010) to compare well with the alternative approaches in terms 
of robustness to non-normality and statistical efficiency, while minimizing non-linear constraints (see Appendix for a summary of Coenders et al. (2008) approach).

We conducted all analyses using full information maximum likelihood with missing data (see Aburckle 1996) using standard errors and test statistics robust to non-normality (Arminger, Sobel 1990; Yuan, Bentler 2000), which is the MLR option in the MPLUS5 program (Muthén, L. K., Muthén, B. O. 2007). Non-normality is a crucial issue when analyzing discrete Likert variables.

\section{Research results}

\subsection{Model specification and fit}

The final SEM included indicators of all constructs in the study and the following additional product indicators for the interaction terms (see Table 1):

1) Interaction between proactive orientation and market changes $\left(x_{1} x_{9}, x_{2} x_{10}, x_{3} x_{11}\right)$.

2) Interaction between proactive orientation and technological changes $\left(x_{1} x_{12}, x_{2} x_{13}\right.$, $\left.x_{3} x_{14}\right)$.

3) Interaction between responsive orientation and market changes $\left(x_{5} x_{9}, x_{6} x_{10}, x_{7} x_{11}\right)$.

4) Interaction between responsive orientation and technological changes $\left(x_{5} x_{12}, x_{6} x_{13}\right.$, $\left.x_{7} x_{14}\right)$.

The equations that related latent variables to one another were:

1) Innovation success regressed on proactive orientation, responsive orientation, market changes, technological changes, and the four interaction terms above.

2) Market success regressed on innovation success.

The model included all error covariances for pairs of overlapping product indicators (such as $x_{1} x_{9}$ and $x_{1} x_{12}$ or $x_{1} x_{12}$ and $x_{5} x_{12}$ ). These error covariances (12 in total) are included in the model for methodological reasons and are neither reported nor interpreted in this study (see Appendix). The model also included the error covariances between $y_{2}$ and $y_{3}$, both related to new product share $(t$-value $=6.81)$ and between $y_{4}$ and $y_{5}$, both related to sales value $(t$-value $=5.87)$.

Even if the $\chi^{2}$ test rejected the hypothesis that the model was exactly correct $\left(\chi^{2}=\right.$ 551.14 with 421 degrees of freedom), the model's goodness of fit was excellent and the usual fit indices were better than the commonly accepted thresholds (CFI $=0.961$; the literature recommends values above 0.9 or 0.95 ; $\mathrm{TLI}=\mathrm{NNFI}=0.954$; the literature recommends values above 0.9 or 0.95 ; $90 \%$ confidence interval for RMSEA between 0.020 and 0.032 ; the literature recommends values below 0.05 or 0.08 ).

\subsection{Measures assessment}

Table 1 shows all standardized loadings of $x_{1}$ to $x_{14}$ and $y_{1}$ to $y_{6}$ to be significant (as shown by the $t$-values higher than 1.96); precise (as shown by the narrow confidence intervals); admissible (as shown by their upper confidence limits lower than 1); and of reasonably high magnitude, thus providing support for convergent validity. The smallest $t$-value for the test of unit correlation between any two factors was 4.89 , thus providing support for discriminant validity. 
Table 1. Measurement part of the model

\begin{tabular}{|c|c|c|c|c|}
\hline & Estimate & $t$-value & $\operatorname{lcl}(95 \%)$ & $\operatorname{ucl}(95 \%)$ \\
\hline \multicolumn{5}{|l|}{ Proactive orientation } \\
\hline $\begin{array}{l}x_{1}: \text { We examine which needs and wants } \\
\text { customers may have in the future }\end{array}$ & 0.78 & 22.72 & 0.72 & 0.85 \\
\hline $\begin{array}{l}x_{2}: \text { We try to recognize needs and wants } \\
\text { which existing and potential customers } \\
\text { are unaware of or they don't want to } \\
\text { disclose }\end{array}$ & 0.76 & 21.66 & 0.69 & 0.83 \\
\hline $\begin{array}{l}x_{3}: \text { We examine problems customers may } \\
\text { have with existing products in the market } \\
\text { in order to offer a new or better solution } \\
\text { to satisfy a need }\end{array}$ & 0.77 & 21.64 & 0.70 & 0.84 \\
\hline $\begin{array}{l}x_{4}: \text { We develop new products that will } \\
\text { satisfy still unexpressed customer needs }\end{array}$ & 0.65 & 17.76 & 0.58 & 0.72 \\
\hline \multicolumn{5}{|l|}{ Responsive orientation } \\
\hline $\begin{array}{l}x_{5}: \text { We respond quickly to competitors' } \\
\text { activities }\end{array}$ & 0.77 & 28.03 & 0.72 & 0.83 \\
\hline $\begin{array}{l}x_{6}: \text { Business functions work in } \\
\text { coordinated way so as to satisfy the needs } \\
\text { of our target markets }\end{array}$ & 0.75 & 23.42 & 0.68 & 0.81 \\
\hline $\begin{array}{l}x_{7}: \text { We adapt the marketing mix } \\
\text { (products, prices, distribution, } \\
\text { communications) to the selected target } \\
\text { markets }\end{array}$ & 0.73 & 21.83 & 0.67 & 0.80 \\
\hline $\begin{array}{l}x_{8}: \text { We respond quickly to changed needs, } \\
\text { wants and/or buying behavior }\end{array}$ & 0.78 & 28.10 & 0.73 & 0.84 \\
\hline \multicolumn{5}{|l|}{ Market changes } \\
\hline $\begin{array}{l}x_{9}: \text { Customer needs and wants are } \\
\text { changing fast }\end{array}$ & 0.88 & 40.94 & 0.84 & 0.93 \\
\hline $\begin{array}{l}x_{10}: \text { Customers tend to look for new } \\
\text { products all the time }\end{array}$ & 0.87 & 30.10 & 0.81 & 0.92 \\
\hline $\begin{array}{l}x_{11}: \text { Customer buying behavior is } \\
\text { changing fast }\end{array}$ & 0.79 & 25.85 & 0.73 & 0.85 \\
\hline \multicolumn{5}{|l|}{ Technological changes } \\
\hline $\begin{array}{l}x_{12}: \text { Technological changes provide big } \\
\text { opportunities in our industry }\end{array}$ & 0.86 & 28.78 & 0.80 & 0.92 \\
\hline $\begin{array}{l}x_{13}: \text { The technology in our industry is } \\
\text { changing rapidly }\end{array}$ & 0.82 & 25.24 & 0.75 & 0.88 \\
\hline $\begin{array}{l}x_{14}: \text { A large number of new product } \\
\text { ideas have been made possible through } \\
\text { technological breakthroughs in our } \\
\text { industry }\end{array}$ & 0.72 & 17.14 & 0.63 & 0.80 \\
\hline
\end{tabular}


End of Table 1

\begin{tabular}{|c|c|c|c|c|}
\hline & Estimate & $t$-value & $\operatorname{lcl}(95 \%)$ & $\operatorname{ucl}(95 \%)$ \\
\hline \multicolumn{5}{|l|}{ Proactive orientation*market changes } \\
\hline$x_{1} x_{9}$ & 0.64 & 8.97 & 0.50 & 0.78 \\
\hline$x_{2} x_{10}$ & 0.61 & 8.42 & 0.47 & 0.75 \\
\hline$x_{3} x_{11}$ & 0.57 & 9.97 & 0.46 & 0.68 \\
\hline \multicolumn{5}{|l|}{ Proactive orientation*technological changes } \\
\hline$x_{1} x_{12}$ & 0.52 & 6.63 & 0.37 & 0.68 \\
\hline$x_{2} x_{13}$ & 0.46 & 6.13 & 0.31 & 0.60 \\
\hline$x_{3} x_{14}$ & 0.41 & 6.78 & 0.29 & 0.53 \\
\hline \multicolumn{5}{|l|}{ Responsive orientation*market changes } \\
\hline$x_{5} x_{9}$ & 0.73 & 14.64 & 0.64 & 0.83 \\
\hline$x_{6} x_{10}$ & 0.65 & 9.89 & 0.52 & 0.78 \\
\hline$x_{7} x_{11}$ & 0.60 & 13.27 & 0.51 & 0.69 \\
\hline \multicolumn{5}{|c|}{ Responsive orientation*technological changes } \\
\hline$x_{5} x_{12}$ & 0.65 & 11.22 & 0.54 & 0.76 \\
\hline$x_{6} x_{13}$ & 0.55 & 9.75 & 0.44 & 0.66 \\
\hline$x_{7} x_{14}$ & 0.51 & 9.28 & 0.40 & 0.61 \\
\hline \multicolumn{5}{|l|}{ Innovation success } \\
\hline$y_{1}:$ New-product launch on time & 0.75 & 20.17 & 0.68 & 0.82 \\
\hline $\begin{array}{l}y_{2}: \text { Market share of new product on the } \\
\text { most important market/market segment }\end{array}$ & 0.71 & 17.45 & 0.63 & 0.79 \\
\hline $\begin{array}{l}y_{3}: \text { Percentage of new-product sales in } \\
\text { total sales of the company }\end{array}$ & 0.62 & 12.52 & 0.52 & 0.71 \\
\hline \multicolumn{5}{|l|}{ Market success } \\
\hline$y_{4}:$ Sales value & 0.61 & 12.33 & 0.51 & 0.71 \\
\hline$y_{5}:$ Growth of sales value & 0.63 & 12.97 & 0.53 & 0.72 \\
\hline$y_{6}:$ Customer satisfaction & 0.66 & 13.75 & 0.56 & 0.75 \\
\hline
\end{tabular}

Note: Standardized loadings with $t$-values and $95 \%$ conficence intervals (lcl: lower conficence limit; ucl: upper confidence limit)

Standardized loadings corresponding to product indicators tend to be smaller because product indicators combine the measurement error of both indicators being multiplied. It is thus extremely important to have valid and reliable indicators of the main effect factors when fitting a model that includes interaction or moderator effects.

\subsection{Hypotheses testing}

Table 2 displays the standardized parameters relating the latent variables to one another and Table 3 displays standardized indirect effects. The hypotheses related to the parameters are presented in parentheses. Some variables are not related to any hypothesis, but 
Table 2. Structural part of the model

\begin{tabular}{lcccc}
\hline & & & $\begin{array}{c}\text { lcl } \\
(95 \%)\end{array}$ & ucl (95\%) \\
\hline Innovation success regressed on $\left(\mathrm{R}^{2}=0.53\right)$ : & & & & \\
\hline Proactive orientation (H1a, H2a) & 0.56 & 3.66 & 0.26 & 0.85 \\
Responsive orientation (H1b, H2b) & 0.06 & 0.38 & -0.25 & 0.37 \\
Market changes & 0.18 & 2.59 & 0.04 & 0.32 \\
Technological changes & 0.05 & 0.71 & -0.09 & 0.20 \\
Proactive orientation*market changes (H3a) & -0.19 & -1.48 & -0.44 & 0.06 \\
Responsive orientation*market changes (H3b) & 0.21 & 2.08 & 0.01 & 0.41 \\
Proactive orientation*technological changes & & & & \\
(H4a) & 0.21 & 1.00 & -0.20 & 0.62 \\
Responsive orientation*technological changes & & & & \\
(H4b) & -0.18 & -0.96 & -0.55 & 0.19 \\
\hline Market success regressed on $\left(\mathrm{R}^{2}=0.70\right):$ & & & & \\
\hline Innovation success (H2a, H2b) & 0.84 & 15.30 & 0.73 & 0.94 \\
\hline
\end{tabular}

Standardized coefficients with $t$-values and $95 \%$ conficence intervals (lcl: lower conficence limit; ucl: upper confidence limit). Hypotheses and $\mathrm{R}^{2}$ within parentheses.

Table 3. Indirect effects

\begin{tabular}{lcccc}
\hline & Estimate & $t$-value & $\begin{array}{c}\text { lcl } \\
(95 \%)\end{array}$ & ucl (95\%) \\
\hline $\begin{array}{l}\text { Market success mediated by innovation } \\
\text { success regressed on }\end{array}$ & & & & \\
\hline Proactive orientation (H2a) & 0.47 & 3.53 & 0.21 & 0.72 \\
Responsive orientation ( H2b) & 0.05 & 0.38 & -0.21 & 0.31 \\
\hline
\end{tabular}

Standardized indirect effects with $t$-values and $95 \%$ conficence intervals (lcl: lower conficence limit; ucl: upper confidence limit). Hypotheses within parentheses.

must be included in the model because their products are included. The percentages of explained variance are high both for market success and for innovation success (above the explained variance for innovation success in Narver et al. 2004). Hypothesis H1a is confirmed with respect to proactive orientation, which has a direct, positive, and significant effect of considerable magnitude on innovation success. This translates into an indirect effect on market success via the close positive relationship between both types of success $(\mathrm{H} 2 \mathrm{a})$. With respect to responsive orientation $(\mathrm{H} 1 \mathrm{~b}$ and $\mathrm{H} 2 \mathrm{~b}$ ) we found no significant effect. Colinearity between both types of orientation is high, but not dramatic (factor correlation 0.83). However, it likely contributes to a high standard error, which translates into a somewhat wide confidence interval for the effect of responsive orientation on innovation success. This effect might actually exist and be as large as 0.37 standardized units according to the confidence interval. 
Hypothesis $\mathrm{H} 3 \mathrm{~b}$ is confirmed with respect to responsive orientation. The significant positive interaction effect between responsive orientation and market changes is interpreted as a positive effect of responsive orientation on innovation success when market changes are rapid. Hypotheses $\mathrm{H} 3 \mathrm{a}, \mathrm{H} 4 \mathrm{a}$, and $\mathrm{H} 4 \mathrm{~b}$ are not confirmed. All three interactions are far from being statistically significant.

\section{Discussion and implications}

In general, the results suggest that proactive market orientation is a determinant of innovation success and, in turn, market success of the organization. These findings thereby provide additional support for extant empirical findings that reveal the importance of proactive market orientation for a new-product success (Narver et al. 2004; AtuaheneGima et al. 2005; Tsai et al. 2008). According to the present study, companies can improve their innovation success (measured by new products launching on time; market share of new products on the most important market; and percentage of new product sales to total company sales relative to the company's objectives) by improving their proactive market orientation. In addition, a higher level of proactive market orientation can enhance market success via its positive effect of innovation success. Organizations are therefore advised to invest resources in raising the level of their proactive market orientation. They can achieve this by investing resources in exploring latent and future customer needs; examining problems customers might have with existing products to offer better solution to satisfy their needs; and developing new products to satisfy latent customer needs.

Contrary to expectations, this study reveals an insignificant moderating effect of above average market and technological changes on the relationship between a proactive market orientation and innovation success. While none of the prior empirical studies examined the moderating effect of market changes on the relationship between a proactive market orientation and innovation success, this study's finding on the insignificant moderating effect of technological changes counters the results reported by Tsai et al. (2008) who found an inverted U-shaped relationship between proactive market orientation and new product performance in a stable technological environment. Tsai et al.'s (2008) results implied that in a stable technological environment, a proactive market orientation becomes detrimental to a new product performance beyond a certain level. A possible explanation for the discordant results of both studies may lie in the different sample characteristics. While Tsai et al. (2008) obtained results only from a high tech sector, this study included organizations from diverse, high-tech, and non-high tech sectors.

A complementary view to proactive market orientation is responsive market orientation. This means that companies respond to competitor's activities; adapt their marketing mix to the target market; and respond quickly to changed needs or buying behavior. In general, the study reveals an insignificant relationship between a responsive market orientation and innovation success. This provides additional support for the results reported by Narver et al. (2004) who found that only a proactive market orientation is 
significantly related to new product success. Our study, however, also reveals that the relationship between responsive market orientation and innovation success depends on the degree of market changes. The impact of responsive market orientation on innovation success is positive and significant under higher levels of market changes, while it is insignificant for average or below average turbulent markets. When customer needs and buying behavior are changing rapidly, a company can increase its innovation success by quickly responding to the market changes. On the other hand, technological changes have no moderating effect on the relationship between responsive market orientation and innovation success. This implies that regardless of the level of technological changes, satisfying expressed customer needs is not sufficient for innovation success. The result also contradicts findings reported by Tsai et al. (2008) who found a strong, negative relationship between a responsive market orientation and new product performance under high technological turbulence and an insignificant relationship under a stable technological environment. Again, the discordant findings of both studies may be explained by the different sample characteristics.

To summarize, while proactive market orientation positively influences an organization's innovation and market success regardless of environmental turbulence, the impact of responsive market orientation on innovation and market success is positive and significant only in a rapidly changing market environment.

Based on our study, we provide the following strategic recommendations for innovative companies. Managers are advised to invest relatively more efforts and resources in improving a proactive market orientation as this can lead to a better innovation performance and, in turn, to a better market success. However, it is also important that companies improve their responsive market orientation, in particular companies operating in a rapidly changing market environment. As Narver et al. (2004) point out companies should always first consider the expressed customer needs because they are in the consciousness of the customer. Hence, both market orientations are needed. This is in line with a broader view, that the winners will be companies that are responsive to challenges and adroit in both creating opportunities and capturing them (Radović Marković 2008). However, responsive market-oriented behaviors can and will be imitated successfully (Narver et al. 2004); companies are therefore strongly advised to continuously develop their capability of recognizing, understanding and satisfying latent needs in order to create and to maintain sustainable competitive advantage. Moreover, a market orientation can only be a source of comparative advantage if it is rare among competitors (Hunt, Morgan 1995), therefore companies should constantly strive to develop a higher level of market orientation (in particular a proactive market orientation) relative to their competitors. Finally, market orientation will have more value and exhibit greater rarity and inimitability when it is complemented by other resources and capabilities, such as innovativeness (Menguc, Auh 2006). Hence, companies are recommended to develop unique bundles of resources and capabilities (e.g. Ginevičius, Korsakiene 2005; Strandskov 2006).

The findings contribute to the existing knowledge on the relationship between market orientation and innovation success in several ways. The main contribution lies in adop- 
ting both responsive and proactive market orientations to examine the impact of market orientation on innovation success and, in turn, on market performance. Although the recent market orientation literature has emphasized the importance of measuring both forms of market orientation, the number of empirical studies adopting both forms of market orientation has been very limited. To our knowledge, this is the first study that examines the entire chain of relationships from market orientation via innovation success on market performance by adopting both a responsive and proactive market orientation. Prior empirical studies have examined only the relationship between both forms of market orientation and new product success (Narver et al. 2004; Atuahene-Gima et al. 2005; Tsai et al. 2008). In addition, the existing empirical studies that distinguish between a responsive and proactive market orientation were conducted in non-European countries. Hence, our study is the first that addresses both forms of market orientation in the context of companies from a European country. A further contribution of this study lies in examining the moderating effect of market changes on the relationship between both forms of market orientation and innovation success. No prior empirical studies on both forms of market orientation have examined the moderating effect of market changes whereas only a few empirical studies have examined the role of technological turbulence (e.g. Tsai et al. 2008). Because the study is a cross-industry survey and not limited to a high-tech sector (Tsai et al. 2008), it broadens the scope of research and provides more opportunities for generalizing the results across different sectors/industries. Finally yet importantly, in its methodological approach, this study uses multiple items to measure innovation success and market success and accounts for measurement error bias by means of non-linear structural equation models.

There are also a number of limitations to the study. First, it is a cross-sectional study. In the future, a longitudinal approach would be useful to tap into the dynamics of the phenomena of interest (e.g. Rindfleisch et al. 2008). Second, the study is based on subjective data, i.e. managers' perceptions of all constructs under review, including innovation success and market success. According to Hult et al. (2008), the sole use of primary measures of performance may not capture the full dimensions of performance, and may instead result in single source bias and common method variance. This leads to the need for additional, secondary measures of performance. Although it is suggested to use both primary and secondary sources of data whenever possible in measuring firm performance (Hult et al. 2008), the secondary (objective) measures were not obtainable for this study.

Third, the response rate in the survey is relatively low (i.e., 16\%). Low response was expected due to the chosen form of an Internet survey and the length of the complete questionnaire. Nevertheless, it is within the range for top management survey response rates (e.g. Voola, O'Cass 2010), also, in terms of the sample size, the study exceeds samples used in other similar empirical studies (Narver et al. 2004; Atuahene-Gima et al. 2005; Tsai et al. 2008).

Fourth, the understanding of how to measure responsive and proactive market orientation properly is still developing. Further testing of measures is therefore essential. In future research, it would be useful to consider that a company may be proactive only 
in specific, selected markets and/or product categories and not in others. Understanding the impact of responsive and proactive market orientation on firm performance in this context is still limited.

Fifth, the literature implies that each form of market orientation leads to innovations with different degrees of innovativeness. It is expected that responsive market orientation would have a relatively greater impact on incremental innovation, while a proactive market orientation would have a greater impact on radical innovation. In future research, it would be useful to test these relationships under different environmental conditions.

\section{APPENDIX}

Assume we have a model with two explanatory factors $f_{1}$ and $f_{2}$, each measured with three indicators $x_{1}, x_{2}, x_{3}, x_{4}, x_{5}, x_{6}$ in a conventional confirmatory factor analysis model. The first indicator is used to fix the scale of the factor by means of a unit factor loading $\left(\lambda_{11}=\right.$ $\left.\lambda_{42}=1\right)$.

$$
\begin{gathered}
x_{1}=f_{1}+e_{1}, \\
x_{2}=\lambda_{21} f_{1}+e_{2}, \\
x_{3}=\lambda_{31} f_{1}+e_{3}, \\
x_{4}=f_{2}+e_{4}, \\
x_{5}=\lambda_{52} f_{2}+e_{5}, \\
x_{6}=\lambda_{62} f_{2}+e_{6} .
\end{gathered}
$$

We are interested in the interaction or moderator effect between $f_{1}$ and $f_{2}$ on a certain dependent variable and we thus need indicators for the non observed product between $f_{1}$ and $f_{2}$ which is defined a new latent variable $f_{3}=f_{1} f_{2}$. For this purpose:

1) We center $x_{1}, x_{2}, x_{3}, x_{4}, x_{5}, x_{6}$ on their mean value.

2) We select three pairs of centered indicators of $f_{1}$ and $f_{2}$ in such a way that each indicator is used only once, we compute their products and we use them as observable indicators of the latent interaction. Ideally, one pair uses the indicators with unit loadings. For instance:

$$
\begin{gathered}
x_{7}=x_{1} x_{4}=f_{3}+e_{7}, \\
x_{8}=x_{2} x_{5}=\lambda_{83} f_{3}+e_{8}, \\
x_{9}=x_{3} x_{6}=\lambda_{93} f_{3}+e_{9} .
\end{gathered}
$$

3) We introduce the following constraints on the loadings of the product indicators as products of the loadings of the original indicators. This step is not essential if the user's software does not support this type of constraints, but if it can be done it does increase the efficiency of estimates (Coenders et al. 2008). This constraint applies to unstandardized loadings, not to their standardized counterparts.

$$
\begin{aligned}
& \lambda_{83}=\lambda_{21} \lambda_{52}, \\
& \lambda_{93}=\lambda_{31} \lambda_{62} .
\end{aligned}
$$

4) We complete the SEM in the usual way with the addition of the dependent latent variables and their equations which relate them to the explanatory latent variables $f_{1}$, 
$f_{2}$ and $f_{3}$, the last of which is interpreted as the product $f_{1} f_{2}$. Note that whenever $f_{3}$ is in the model, $f_{1}$ and $f_{2}$ also have to be, even if they are not statistically significant or theoretically relevant (Irwin, McClelland 2001).

5) We estimate the SEM by ignoring the mean structure (or equivalently by leaving an unrestricted intercept term for each observed variable and setting the means of all latent variables to zero).

6) We interpret all results in the usual way except standardized estimates of $f_{3}$ on the dependent variables. Such estimates can be interpreted as the sign and size of the moderator effects, but not as exact changes in the effect of $f_{1}$ on the dependent variable when $f_{2}$ changes by one standardized unit. This is so because standardization makes $f_{3}$ proportional to the product $f_{1} f_{2}$ but not identical to it (Irwin, McClelland 2001).

7) If $f_{1}$ and $f_{2}$ have a different number of indicators, the minimum number of indicators of both will correspond to the number of indicators of the interaction. Some of the indicators of the factor with the larger number will thus not be used in any product.

8) If the interactions between more than two factors have to be estimated, it is unavoidable that some indicators are used more than once when forming the product indicators. This will generate a correlation between the measurement error terms of any two product indicators which share an original indicator. These error correlations have to be included in the model as additional parameters.

\section{References}

Aburckle, J. L. 1996. Full information estimation in the presence of incomplete data, in Marcoulides, G. A.; Schumacker, R. E. (Eds.). Advanced Structural Equation Modeling. Mahwah, NJ: Erlbaum, 243-277.

Anderson, E. W.; Fornell, C.; Mazvancheryl, S. K. 2004. Customer satisfaction and shareholder value, Journal of Marketing 68(4): 172-185. http://dx.doi.org/10.1509/jmkg.68.4.172.42723

Appiah-Adu, K. 1998. Market orientation and performance: empirical tests in a transition economy, Journal of Strategic Marketing 6(1): 25-45. http://dx.doi.org/10.1080/096525498346685

Arminger, G.; Sobel, M. E. 1990. Pseudo maximum likelihood estimation of mean and covariance structures with missing data, Journal of the American Statistical Association 85: 195-203. http://dx.doi.org/10.2307/2289545

Atuahene-Gima, K. 1995. An exploratory analysis of the impact of market orientation on new product development, Journal of Product Innovation Management 12(4): 275-293.

http://dx.doi.org/10.1016/0737-6782(95)00027-Q

Atuahene-Gima, K.; Slater, S. F.; Olson, E. M. 2005. The contingent value of responsive and proactive market orientations for new product program performance, Journal of Product Innovation Management 22(6): 464-482. http://dx.doi.org/10.1111/j.1540-5885.2005.00144.x

Baker, W.; Sinkula, J. M. 1999a. The synergistic effect of market orientation and learning orientation on organizational performance, Journal of the Academy of Marketing Science 27(4): 411-427. http://dx.doi.org/10.1177/0092070399274002

Baker, W. E.; Sinkula, J. M. 1999b. Learning orientation, market orientation, and innovation: integrating and extending models of organizational performance, Journal of Market-Focused Management 4(4): 295-308. http://dx.doi.org/10.1023/A:1009830402395

Baker, W. E.; Sinkula, J. M. 2005. Market orientation and the new product paradox, Journal of Product Innovation Management 22(6): 483-502.

http://dx.doi.org/10.1111/j.1540-5885.2005.00145.x 
Berthon, P.; Hulbert, J. M.; Pitt, L. 2004. Innovation or customer orientation? An empirical investigation, European Journal of Marketing 38(9/10): 1065-1090.

http://dx.doi.org/10.1108/03090560410548870

Cahill, D. J.; Thach, S. V.; Warshawsky, R. M. 1994. From experience: the marketing concept and new high-tech products: is there a fit?, Journal of Product Innovation Management 11(4): 336-343. http://dx.doi.org/10.1016/0737-6782(94)90088-4

Calantone, R.; Garcia, R.; Dröge, C. 2003. The effects of environmental turbulence on new product development strategy planning, Journal of Product Innovation Management 20(2): 90-103. http://dx.doi.org/10.1111/1540-5885.2002003

Cano, C. R.; Carrillat, F. A.; Jaramillo, F. 2004. A meta-analysis of the relationship between market orientation and business performance: evidence from five continents, International Journal of Research in Marketing 21(2): 179-200. http://dx.doi.org/10.1016/j.ijresmar.2003.07.001

Christensen, C. M.; Bower, J. L. 1996. Customer power, strategic investment, and the failure of leading firms, Strategic Management Journal 17(3): 197-218.

http://dx.doi.org/10.1002/(SICI)1097-0266(199603)17:3<197::AID-SMJ804>3.0.CO;2-U

Coenders, G.; Batista-Foguet, J. M.; Saris, W. E. 2008. Simple, efficient and distribution-free approach to interaction effects in complex structural equation models, Quality \& Quantity 42: 369-396. http://dx.doi.org/10.1007/s11135-006-9050-6

Cooper, R. G. 1994. New products: the factors that drive success, International Marketing Review 11(1): 60-76. http://dx.doi.org/10.1108/02651339410057527

Cooper, R. G.; Kleinschmidt, E. J. 1994. Determinants of timeliness in product development, Journal of Product Innovation Management 11(5): 381-396.

http://dx.doi.org/10.1016/0737-6782(94)90028-0

Cooper, R. G.; Kleinschmidt, E. J. 1995. Benchmarking the firm's critical success factors in new product development, Journal of Product Innovation Management 12(5): 374-391.

http://dx.doi.org/10.1016/0737-6782(95)00059-3

Davila, T.; Epstein, M. J.; Shelton, R. 2006. Making Innovation Work: How to Manage It, Measure It and Profit from It. Upper Saddle River, Wharton School Publishing.

Dawes, J. 1999. The relationship between subjective and objective company performance measures in market orientation research: further empirical evidence, Marketing Bulletin 10(May): 65-75.

Day, G.; Wensley, R. 1988. Assessing advantage: a framework for diagnosing competitive superiority, Journal of Marketing 52(2): 1-20. http://dx.doi.org/10.2307/1251261

Deshpande, R.; Farley, J. U.; Webster, F. E. Jr. 1993. Corporate culture, customer orientation, and innovativeness in Japanese firms: a quadrad analysis, Journal of Marketing 57(1): 23-27.

http://dx.doi.org/10.2307/1252055

Deshpande, R.; Farley, J. U. 2004. Organizational culture, market orientation, innovativeness, and firm performance: an international research odyssey, International Journal of Research in Marketing 21(1): 3-22. http://dx.doi.org/10.1016/j.ijresmar.2003.04.002

Diamantopoulos, A.; Hart, S. 1993. Linking market orientation and company performance: preliminary evidence on Kohli and Jaworski's framework, Journal of Strategic Marketing 1(2): 92-121.

Ellis, P. D. 2006. Market orientation and performance: a meta-analysis and cross-national comparisons, Journal of Management Studies 43(5): 1089-1107.

http://dx.doi.org/10.1111/j.1467-6486.2006.00630.x

Fagerberg, J. 2005. Innovation: a guide to the literature, in Fagerberg, J.; Mowery, D. C.; Nelson, R. R. (Eds.). The Oxford Handbook of Innovation. New York: Oxford University Press Inc., 1-26. 
Ginevičius, R.; Korsakiene, R. 2005. Exploration of strategy: objectives, competencies and competitive advantage, Journal of Business Economics and Management 6(1): 13-22.

Gonzalez-Benito, O.; Gonzalez-Benito, J.; Munoz-Gallego, P. A. 2009. Role of entrepreneurship and market orientation in firm's success, European Journal of Marketing 43(3/4): 500-522.

Gray, B. J.; Greenley, G. E.; Matear, S. M.; Matheson, P. K. 1999. Thriving on turbulence, Journal of Market-Focused Management 4(3): 231-257. http://dx.doi.org/10.1023/A:1009827103329

Greenley, G. E. 1995. Market orientation and company performance: empirical evidence from UK companies, British Journal of Management 6(1): 1-13.

http://dx.doi.org/10.1111/j.1467-8551.1995.tb00082.x

Griffin, A.; Hauser, J. R. 1996. Integrating R\&D and marketing: a review and analysis of the literature, Journal of Product Innovation Management 13(3): 191-215.

http://dx.doi.org/10.1111/1540-5885.1330191

Grinstein, A. 2008. The effect of market orientation and its components on innovation consequences: a meta-analysis, Journal of the Academy of Marketing Science 36(2): 166-173.

http://dx.doi.org/10.1007/s11747-007-0053-1

Gruca, T. S.; Rego, L. L. 2005. Customer satisfaction, cash flow, and shareholder value, Journal of Marketing 69(3): 115-130.

Hamel, G.; Prahalad, C. K. 1991. Corporate imagination and expeditionary marketing, Harvard Business Review 69(4): 81-92.

Han, J. K.; Kim, N.; Srivastava, R. K. 1998. Market orientation and organizational performance: is innovation a missing link?, Journal of Marketing 62(4): 30-45. http://dx.doi.org/10.2307/1252285

Henard, D. H.; Szymanski, D. M. 2001. Why some new products are more successful than others, Journal of Marketing Research 38(3): 362-375. http://dx.doi.org/10.1509/jmkr.38.3.362.18861

Homburg, C.; Pflesser, C. 2000. A multiple-layer model of market-oriented organizational culture: measurement issues and performance outcomes, Journal of Marketing Research 37(4): 449-462. http://dx.doi.org/10.1509/jmkr.37.4.449.18786

Hooley, G.; Cox, T.; Fahy, J.; Shipley, D.; Beracs, J.; Fonfara, K.; Snoj, B. 2000. Market orientation in the transition economies of Central Europe: tests of the Narver and Slater market orientation scales, Journal of Business Research 50(3): 273-285.

http://dx.doi.org/10.1016/S0148-2963(99)00105-8

Hooley, G.; Fahy, J.; Greenley, G.; Beracs, J.; Fonfara, K.; Snoj, B. 2003. Market orientation in the service sector of the transition economies of Central Europe, European Journal of Marketing 37(1/2): 86-106. http://dx.doi.org/10.1108/03090560310453975

Hooley, G. J.; Greenley, G. E.; Cadogan, J. W.; Fahy, J. 2005. The performance impact of marketing resources, Journal of Business Research 58(1): 18-27.

http://dx.doi.org/10.1016/S0148-2963(03)00109-7

Hult, G. T. M.; Ketchen, D. J. Jr. 2001. Does market orientation matter? A test of the relationship between positional advantage and performance, Strategic Management Journal 22(9): 899. http://dx.doi.org/10.1002/smj.197

Hult, G. T. M.; Ketchen, D. J.; Griffith, D. A.; Chabowski, B. R.; Hamman, M. K.; Dykes, B. J., et al. 2008. An assessment of the measurement of performance in international business research, Journal of International Business Studies 39(6): 1064-1080.

http://dx.doi.org/10.1057/palgrave.jibs.8400398

Hunt, S. D.; Morgan, R. M. 1995. The comparative advantage theory of competition, Journal of Marketing 59(2): 1-15. http://dx.doi.org/10.2307/1252069

Irwin, J. R.; McClelland, G. H. 2001. Misleading heuristics and moderate regression models, Journal of Marketing Research 38: 100-109. http://dx.doi.org/10.1509/jmkr.38.1.100.18835 
Jaccard, J.; Wan, C. K. 1996. Lisrel Approaches to Interaction Effects in Multiple Regression. Thousand Oaks, Ca: Sage.

Jaworski, B. J.; Kohli, A. K. 1993. Market orientation: antecedents and consequences, Journal of Marketing 57(3): 53-70. http://dx.doi.org/10.2307/1251854

Jaworski, B.; Kohli, A.; Sahay, A. 2000. Market-driven versus driving markets, Journal of the Academy of Marketing Science 28(1): 45-54. http://dx.doi.org/10.1177/0092070300281005

Jensen, B.; Harmsen, H. 2001. Implementation of success factors in new product development the missing links?, European Journal of Innovation Management 4(1): 37-52.

http://dx.doi.org/10.1108/14601060110365565

Jöreskog, K. G.; Yang, F. 1996. Nonlinear structural equation models: the Kenny-Judd model with interaction effects, in Marcoulides, G. A.; Schumacker, R. E. (Eds.). Advanced Structural Equation Modeling. Mahwah, NJ: Lawrence Erlbaum, 57-89.

Kenny, D. A.; Judd, C. M. 1984. Estimating the non-linear and interactive effects of latent variables, Psychological Bulletin 96: 201-210. http://dx.doi.org/10.1037/0033-2909.96.1.201

Kirca, A. H.; Jayachandran, S.; Bearden, W. O. 2005. Market orientation: a meta-analytic review and assessment of its antecedents and impact on performance, Journal of Marketing 69(2): 24-41. http://dx.doi.org/10.1509/jmkg.69.2.24.60761

Kohli, A. K.; Jaworski, B. J. 1990. Market orientation: the construct, research propositions, and managerial implications, Journal of Marketing 54(2): 1-18. http://dx.doi.org/10.2307/1251866

Kohli, A. K.; Jaworski, B. J.; Kumar, A. 1993. MARKOR: a measure of market orientation, Journal of Marketing Research 30(4): 467-477. http://dx.doi.org/10.2307/3172691

Kumar, K.; Subramanian, R.; Yauger, C. 1998. Examining the market orientation - performance relationship: a context-specific study, Journal of Management 24(2): 201-233.

Lado, N.; Maydeu-Olivares, A. 2001. Exploring the link between market orientation and innovation in the European and US insurance markets, International Marketing Review 18(2): 130-144. http://dx.doi.org/10.1108/02651330110389972

Langerak, F.; Hultink, E.; Robben, H. S. J. 2004. The impact of market orientation, product advantage, and launch proficiency on new product performance and organizational performance, Journal of Product Innovation Management 21(2): 79-94.

http://dx.doi.org/10.1111/j.0737-6782.2004.00059.x

Lin, G. C.; Wen, Z.; Marsh, H.; Lin, H. S. 2010. Structural equation models of latent interactions: clarification of orthogonalizing and double-mean-centering strategies, Structural Equation Modeling 17(3): 374-391. http://dx.doi.org/10.1080/10705511.2010.488999

Lukas, B. A.; Ferrell, O. C. 2000. The effect of market orientation on product innovation, Journal of the Academy of Marketing Science 28(2): 239-247. http://dx.doi.org/10.1177/0092070300282005

Marsh, H. W.; Wen, Z.; Hau, K. T. 2004. Structural equation models of latent interactions: evaluation of alternative estimation strategies and indicator construction, Psychological Methods 9: 275-300. http://dx.doi.org/10.1037/1082-989X.9.3.275

Matsuno, K.; Mentzer, J. T.; Özsomer, A. 2002. The effects of entrepreneurial proclivity and market orientation on business performance, Journal of Marketing 66(3): 18-32.

http://dx.doi.org/10.1509/jmkg.66.3.18.18507

Menguc, B.; Auh, S. 2006. Creating a firm-level dynamic capability through capitalizing on market orientation and innovativeness, Journal of the Academy of Marketing Science 34(1): 63-73. http://dx.doi.org/10.1177/0092070305281090

Mohr, J. J.; Sarin, S. 2009. Drucker's insights on market orientation and innovation: implications for emerging areas in high-technology marketing, Journal of the Academy of Marketing Science 37(1): 85-96. http://dx.doi.org/10.1007/s11747-008-0101-5 
Muthén, L. K.; Muthén, B. O. 2007. Mplus. Statistical Analysis with Latent Variables. User's Guide. 5th ed. Los Angeles, CA: Muthén and Muthén.

Narver, J. C.; Slater, S. F. 1990. The effect of a market orientation on business profitability, Journal of Marketing 54(4): 20-35. http://dx.doi.org/10.2307/1251757

Narver, J. C.; Slater, S. F.; MacLachlan, D. L. 2004. Responsive and proactive market orientation and new-product success, Journal of Product Innovation Management 21(5): 334-347.

http://dx.doi.org/10.1111/j.0737-6782.2004.00086.x

Papastathopoulou, P. G.; Gounaris, S. P.; Avlonitis, G. J. 2006. Successful new-to-the-market versus "me-too" retail financial services, International Journal of Bank Marketing 24(1): 53-70. http://dx.doi.org/10.1108/02652320610642344

Pelham, A. M.; Wilson, D. T. 1996. A longitudinal study of the impact of market structure, firm structure, strategy, and market orientation culture on dimensions of small-firm performance, Journal of the Academy of Marketing Science 24(1): 27-43. http://dx.doi.org/10.1007/BF02893935

Radović Marković, M. 2008. Managing the organizational change and culture in the age of globalization, Journal of Business Economics and Management 9(1): 3-11.

http://dx.doi.org/10.3846/1611-1699.2008.9.3-11

Rindfleisch, A.; Malter, A. J.; Ganesan, S.; Moorman, C. 2008. Cross-sectional versus longitudinal survey research: concepts, findings, and guidelines, Journal of Marketing Research 45(3): 261-279. http://dx.doi.org/10.1509/jmkr.45.3.261

Rose, G. M.; Shoham, A. 2002. Export performance and market orientation: establishing and empirical link, Journal of Business Research 55(3): 217-225.

http://dx.doi.org/10.1016/S0148-2963(00)00139-9

Sheth, J. N.; Sisodia, R. S. 1999. Revisiting marketing's lawlike generalizations, Journal of the Academy of Marketing Science 27(1): 71-87. http://dx.doi.org/10.1177/0092070399271006

Slater, S. F. 2001. Guru's view: market orientation at the beginning of a new millennium, Managing Service Quality 11(4): 230-232. http://dx.doi.org/10.1108/EUM0000000005609

Slater, S. F.; Narver, J. C. 1994. Does competitive environment moderate the market orientation performance relationship?, Journal of Marketing 58(1): 46-55. http://dx.doi.org/10.2307/1252250

Slater, S. F.; Narver, J. C. 1998. Research notes and communications: market-oriented is more than being customer-led: let's not confuse the two, Strategic Management Journal 19(10): 10011006. http://dx.doi.org/10.1002/(SICI)1097-0266(199810)19:10<1001::AID-SMJ996>3.0.CO;2-4

Strandskov, J. 2006. Sources of competitive advantage and business performance, Journal of Business Economics and Management 7(3): 119-129.

Subramanian, R.; Gopalakrishna, P. 2001. The market orientation - performance relationship in the context of a developing economy, Journal of Business Research 53(1): 1-13.

http://dx.doi.org/10.1016/S0148-2963(99)00109-5

Tsai, K.; Chou, C.; Kuo, J. 2008. The curvilinear relationships between responsive and proactive market orientations and new product performance: a contingent link, Industrial Marketing Management 37(8): 884-894. http://dx.doi.org/10.1016/j.indmarman.2007.03.005

Voola, R.; O'Cass, A. 2010. Implementing competitive strategies: the role of responsive and proactive market orientations, European Journal of Marketing 44(1/2): 245-266.

http://dx.doi.org/10.1108/03090561011008691

Wren, B. M.; Souder, W. E.; Berkowitz, D. 2000. Market orientation and new product development in global industrial firms, Industrial Marketing Management 29(6): 601-611.

http://dx.doi.org/10.1016/S0019-8501(00)00120-6

Yuan, K. H.; Bentler, P. M. 2000. Three likelihood-based methods for mean and covariance structure analysis with nonnormal missing data, in Sobel, M. E.; Becker, M. E. (Eds.). Sociological Methodology. Washington, DC: American Sociological Association, 165-200. 
Mateja BODLAJ. Ph.D. is a teaching assistant at the Faculty of Economics, Department of Marketing, University of Ljubljana. Before her affiliation with the university she worked four years as a program manager in the marketing department of a Slovenian large company. Her research interests involves the role of market orientation, branding and retail internationalization. In 2009, she finished her doctoral disertation addressing the relationship between market orientation, innovation and business performance.

Germa COENDERS is Ph.D. in Management and Business Administration by ESADE, University Ramon Llull, Spain and currently associate professor of quantitative methods for economics and Business at the University of Girona, Spain. He is among the founding members of the European Survey Research Association. He has published over 30 journal articles on methodological issues of social science research.

Vesna ZABKAR. Ph.D. is a Full Professor of Marketing and Head of the Institute for Marketing at the Faculty of Economics of the University of Ljubljana as well as Visiting Professor at the Chair of International Marketing, BWZ, University of Vienna. Before her affiliation with the Slovenian university she worked in the Marketing Department of BOSCH Gmbh, Karlsruhe, Germany. She completed an MBA programme at the University of Ljubljana and was a Fulbright Visiting Scholar in a doctoral programme at the J. L. Kellogg Graduate School of Management, Northwestern University, Evanston, Illinois. She is the author and co-author of several articles published in professional and scientific journals in Slovenia and internationally. Her research interests involve marketing relationships, marketing communications and business-to-business marketing. 